\title{
THE PROGNOSTIC SIGNIFICANCE OF LYMPHOVASCULAR SPACE INVOLVEMENT IN PATIENTS WITH UTERINE- CONFINED ENDOMETRIOID ENDOMETRIAL CANCER
}

\author{
Soyi Lim, MD, Kwang-Beom Lee, MD, Chan-Yong Park, MD \\ Department of Obstetrics and Gynecology, Gachon University Gil Hospital, Gachon University of Medicine and Science, Incheon, Korea
}

\section{Objective}

We evaluated whether or not lymphovascular space involvement (LVSI) is a risk factor for the relapse of disease in patients with uterine-confined endometrioid endometrial cancer.

\section{Methods}

A retrospective chart review was carried out of 165 patients with uterine confined endoemtrioid-type endometrial cancer after initial treatments including total abdominal or laparoscopic hysterectomy, and bilateral salpingo-oophorectomy, with or without lymphadenectomy, peritoneal washing between 1998 and 2010. The patients with positive peritoneal cytology were not excluded.

\section{Results}

The median age was 52 years (range, 26 to 81 years) with a median follow-up of 46 months (range, 1 to 144 months). One hundred twenty-four patients $(75.2 \%)$ received no adjuvant treatment, 41 patients $(24.8 \%)$ received adjuvant treatment including platinumbased chemotherapy, radiation therapy, and chemoradiation. LVSI was present in 29 patients (17.6\%). Eight patients (4.8\%) developed recurrences. Using univariate analysis, age $>50$ years, the tumor grade, and LVSI were found to relate to recurrence-free survival $(P<0.05)$. LVSI was associated with other prognostic factors such as old age, a higher tumor grade, and deeper myometrial invasion. But multivariate analysis showed no significance. LVSI was not an independent factor to predict recurrence $(P=0.093)$.

\section{Conclusion}

LVSI was associated with an increased likelihood of recurrence via univariate analysis in patients with uterine-confined endometrioid endometrial cancer. Multivariate analysis showed no statistical significance. The presence of LVSI seems to have no effect, in and of itself, to alter the treatment plan or to predict the prognosis.

Keywords: Endometrial cancer; lymphatic vessels; Recurrence

Endometrial cancer is the most common gynecological malignancy in the Western world. For patients with a uterine-confined earlystage endometrial carcinoma, the influence of prognostic factors such as patient age, the tumor grade, and the depth of invasion are well-recognized [1]. The presence of lymphovascular space involvement (LVSI) has also been shown to be an independent prognostic factor in several studies, yet its association with recurrence was not shown on the multivariate analysis in other studies [2]. LVSI was associated with compromised survival in patients who are at clinical stages I and II, but not in patients at surgical stages I or II [3].

LVSI has been described as a predictor for nodal metastases or
Received: 2012. 1. 3. Revised: 2012. 1.18. Accepted: 2012. 2. 1. Corresponding author: Chan-Yong Park, MD Department of Obstetrics and Gynecology, Gil Medical School, Gachon University of Medicine and Science, 38 Dokjeom-ro 3beon-gil, Namdong-gu, Incheon 405-835, Korea Tel: +82-32-460-2071 Fax: +82-32-460-3290 E-mail: pcy0523@unitel.co.kr

This is an Open Access article distributed under the terms of the Creative Commons Attribution Non-Commercial License (http://creativecommons.org/licenses/ by-nc/3.0/) which permits unrestricted non-commercial use, distribution, and reproduction in any medium, provided the original work is properly cited.

Copyright $\odot$ 2012. Korean Society of Obstetrics and Gynecology 


\section{KOREAN JOURNAL OF OBSTETRICS \& GYNECOLOGY}

Soyi Lim, et al. LVSI in early stage endometrial cancer

poor survival for several types of gynecologic cancers [4-7]. Once LVSI has occurred, the tumor cells theoretically have the potential to metastasize to regional lymph nodes or further. Thus, LVSI has been noted as an important prognostic factor that is significantly correlated with nodal metastases, tumor recurrence, and patient survival $[1,2,8]$.

The findings of previous studies have been contradictory with respect to the significance of LVSI as an independent prognostic factor. In this study, we focused on patients with uterine-confined endometrioid endometrial cancer. The objective of our study was to evaluate the prognostic significance of lymphovascular space involvement in patients with uterine-confined endometrioid endometrial cancer.

\section{Materials and Methods}

We retrospectively reviewed the pathologic and clinical data on all the patients who were diagnosed with endometrial cancer between January 1998 and June 2010 at the Department of Obstetrics and Gynecology, Gil Hospital, Gachon University of Medicine and Science. All the subjects underwent a total abdominal hysterectomy or laparoscopic hysterectomy, bilateral salpingo-ophorectomy (BSO), peritoneal washing cytology, and with/without lymphadenectomy. The patients with uterine-confined endometrial cancer were included. The histology of all the patients was the endometrioid type and all other histologic subtypes were excluded. The patients with positive peritoneal cytology were not excluded. Clinic-pathologic data such as age, tumor grade, myometrial invasion depth, presence of LVSI, presence of hormone receptor, cervical involvement, and peritoneal cytology were reviewed. LVSI was defined as the presence of viable tumor cells in the endothelial-lined channels, that is, either lymphatics or capillaries, outside the tumor mass. The follow-up consisted of three months for first three years, six months for next two years, and then yearly reviews. The patients were routinely followed for at least 5 years.

Statistical analysis of the data was performed using chi-squre test and Fisher's exact test in univariate analysis. Cox proportional hazard model was used in multivariate analysis. The odds ratios and $95 \%$ confidence intervals were calculated. $P$-values less than 0.05 were considered significant. Statistics were analyzed using SPSS ver. 18.0 (SPSS, Inc., Chicago, IL, USA).

\section{Results}

One hundred sixty-five patients fulfilled the study criteria. All the
Table 1. Clinical characteristics of patients $(n=165)$

\begin{tabular}{|c|c|}
\hline \multicolumn{2}{|l|}{ Variables } \\
\hline Median age, years (range) & $52(26-81)$ \\
\hline Hysterectomy BSO & $46(27.9)$ \\
\hline Hysterectomy BSO PLND & $95(57.6)$ \\
\hline Hysterectomy BSO PLND PALND & $24(14.5)$ \\
\hline \multicolumn{2}{|l|}{ Adjuvant treatment } \\
\hline None & $124(75.2)$ \\
\hline Radiation therapy & $23(13.9)$ \\
\hline Chemotherapy & $12(7.3)$ \\
\hline Platinum-based chemoradiation & $6(3.6)$ \\
\hline Mean retrieved pelvic lymph nodes (range) & $19.9 \pm 16.6(4-73)$ \\
\hline Mean retrieved paraaortic lymph nodes (range) & $1.4 \pm 4.7(2-32)$ \\
\hline
\end{tabular}

patients underwent a hysterectomy with BSO surgical treatment. Pelvic lymph node dissection was performed on ninety-five patients and both pelvic and para-aortic lymph node dissection was performed on twenty-four patients. The mean number of removed pelvic lymph nodes was $19.9 \pm 16.6$ (range, 4 to 73 ) and the mean number of removed para-aortic lymph nodes was $1.4 \pm 4.7$ (range, 2 to 32) (Table 1). Twenty-nine (17.6\%) patients were found to have LVSI. All the cases were negative for lymph node involvement. Adjuvant treatment was administered to the patients: 23 patients received radiation therapy, six received chemoradiotherapy, and 12 received chemotherapy. Eight patients (4.8\%) developed recurrences. The median time to recurrence was 27 months. LVSI was significantly correlated with an increasing depth of myometrial invasion, a higher tumor grade, and age $>50$ years $(P<0.05)$ (Table 2). Five-year progression-free survival was significantly associated with age, a higher tumor grade, and LVSI by univariate analysis (Table 3, Fig. 1). But the pathologic factors were not significant in multivariate analysis (Table 4). The median follow-up of the overall patients was 46 months (range, 1 to 144 months). The five-year progression free-survival rate of all patients was $78 \%$. Recurrence occurred in five patients who have LVSI and in three patients who did not have LVSI (Table 5) and there was no death of disease in our patients.

\section{Discussion}

LVSI is associated with lymph node metastasis and is evaluated ac- 
Table 2. Clinicopathologic factors associated with LVSI $(n=165)$

\begin{tabular}{|c|c|c|c|}
\hline \multirow{2}{*}{ Variables } & \multicolumn{2}{|c|}{ LVSI } & \multirow{2}{*}{$P$-value } \\
\hline & Negative & Positive & \\
\hline \multicolumn{4}{|l|}{ Age (yr) } \\
\hline$\leq 50$ & $69(41.8)$ & $5(3.0)$ & 0.001 \\
\hline$>50$ & $67(40.6)$ & $24(14.6)$ & \\
\hline \multicolumn{4}{|l|}{ Grade } \\
\hline 1 & $109(66.1)$ & $15(9.1)$ & 0.001 \\
\hline 2,3 & $27(16.3)$ & $14(8.5)$ & \\
\hline \multicolumn{4}{|c|}{ Myometrial invasion } \\
\hline$\leq 1 / 2$ & $119(72.1)$ & $16(9.7)$ & $<0.001$ \\
\hline$>1 / 2$ & $17(10.3)$ & $13(7.9)$ & \\
\hline \multicolumn{4}{|c|}{ Cervical involvement } \\
\hline Absent & $119(72.1)$ & $25(15.2)$ & 0.767 \\
\hline Present & $17(10.3)$ & $4(2.4)$ & \\
\hline \multicolumn{4}{|c|}{ Peritoneal cytology } \\
\hline Negative & $126(78.3)$ & $28(17.4)$ & 0.591 \\
\hline Positive & $6(3.7)$ & $1(0.6)$ & \\
\hline NA & 4 & & \\
\hline \multicolumn{4}{|c|}{ Hormone receptor status } \\
\hline Negative & $11(10.5)$ & $4(3.8)$ & 0.28 \\
\hline Positive & $76(72.4)$ & $14(13.3)$ & \\
\hline NA & 60 & & \\
\hline
\end{tabular}

LVSI, lymphovascular involvement; NA, not available.

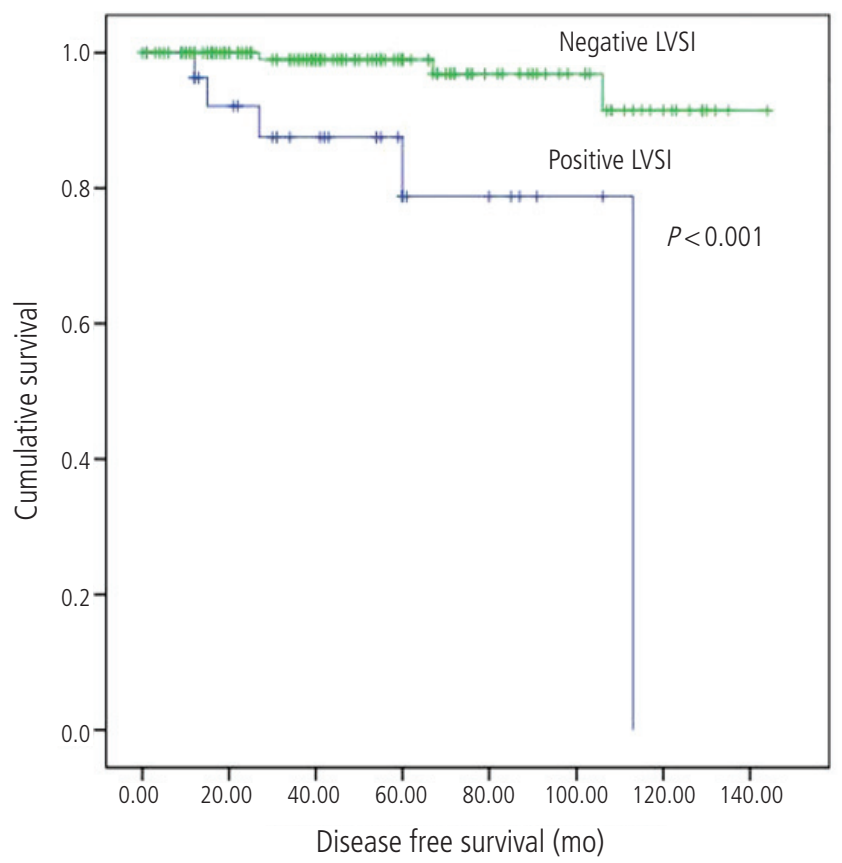

Fig. 1. Survival curve by lymphovascular space involvement status. cording to the tumor grade and depth of invasion in patients with endometrial cancer. Previous studies showed that the tumor grade and the depth of invasion $[9,10]$, as well as LVSI [1,9], are useful predictors for the risk of lymph node metastasis. Some investigators have suggested that LVSI is associated with a risk of vaginal relapse or lymph node metastasis, but LVSI is not associated with distant metastasis in patients with endometrial cancer [2,11-13]. The presence of LVSI cannot be determined before hysterectomy. LVSI is not included among the prognostic indicators of the current Federation of Obstetrics and Gynecology (FIGO) surgical staging classification.

The incidence of LVSI in patients with endometrial cancer is reported to be about $25 \%$ when all the stages and tumor grades are included $[11,14]$. In previous studies, the incidence of LVSI in clinical stage I was 14\%-16\% $[8,9,15]$ and it was $15.5 \%-32.6 \%$ in clinical stages I and II $[3,16]$. The incidence of LVSI was $4.3 \%$ in surgical stages I and II [17] and it was $24.6 \%$ to $34.4 \%$ when all the surgical stages were included $[18,19]$. In the present study, LVSI was positive in 29 patients with uterine-confined endometri- 


\section{KOREAN JOURNAL OF OBSTETRICS \& GYNECOLOGY}

Soyi Lim, et al. LVSI in early stage endometrial cancer

Table 3. Factors associated with recurrence-free survival in univariate analysis $(n=165)$

\begin{tabular}{|c|c|c|c|}
\hline \multirow{2}{*}{ Prognostic factors } & \multirow{2}{*}{ n (\%) } & \multicolumn{2}{|c|}{ Recurrence-free survival } \\
\hline & & 5 -year rate $(\%)$ & $P$-value \\
\hline \multicolumn{4}{|l|}{ Age (yr) } \\
\hline$\leq 50$ & $74(44.8)$ & 100 & 0.028 \\
\hline$>50$ & $91(55.2)$ & 91.7 & \\
\hline \multicolumn{4}{|l|}{ Grade } \\
\hline 1 & $124(75.2)$ & 97.0 & 0.008 \\
\hline 2,3 & $41(24.8)$ & 89.7 & \\
\hline \multicolumn{4}{|l|}{ Myometrial invasion } \\
\hline$\leq 1 / 2$ & $135(81.8)$ & 99.2 & 0.076 \\
\hline$>1 / 2$ & $30(18.2)$ & 87.5 & \\
\hline \multicolumn{4}{|l|}{ Cervical involvement } \\
\hline Absent & $144(87.3)$ & 94.7 & 0.923 \\
\hline Present & $21(12.7)$ & 100 & \\
\hline \multicolumn{4}{|l|}{ Peritoneal cytology } \\
\hline Negative & $154(95.7)$ & 96.2 & 0.787 \\
\hline Positive & $7(4.3)$ & 100 & \\
\hline \multicolumn{4}{|c|}{ Hormone receptor status } \\
\hline Negative & $15(14.3)$ & 82.5 & 0.135 \\
\hline Positive & $90(85.7)$ & 95.9 & \\
\hline \multicolumn{4}{|c|}{ Lymphovascular space invasion } \\
\hline Negative & $136(82.4)$ & 99.0 & $<0.001$ \\
\hline Positive & $29(17.6)$ & 78.8 & \\
\hline
\end{tabular}

Table 4. Factors associated with recurrence-free survival in multivariate analysis ( $n=165)$

\begin{tabular}{|lccc|}
\hline \multirow{2}{*}{ Variables } & \multicolumn{3}{c|}{ Recurrence-free survival } \\
\cline { 2 - 4 } & OR & $\mathbf{9 5 \%} \mathbf{C l}$ & $\boldsymbol{P}$-value \\
\hline Grade 2, & 4.124 & $0.78-21.582$ & 0.093 \\
LVSI presence & 4.715 & $0.771-28.822$ & 0.093 \\
Age $>50$ yr & 4.873 & $0.454-82.260$ & 0.191 \\
Myometrial invasion>1/2 & 0.683 & $0.107-4.375$ & 0.683 \\
\hline
\end{tabular}

$\mathrm{OR}$, odds rations; $\mathrm{Cl}$, confidence intervals; LVSI, lymphovascular involvement.

Table 5. Details of patients with recurrence

\begin{tabular}{|cccccccl|}
\hline Patients & $\begin{array}{c}\text { Age } \\
\text { (yr) }\end{array}$ & $\begin{array}{c}\text { Myometrial } \\
\text { invasion }\end{array}$ & Grade & LVSI & $\begin{array}{c}\text { Time to } \\
\text { recurrence (mo) }\end{array}$ & $\begin{array}{c}\text { Adjuvant } \\
\text { treatment }\end{array}$ & Recur site \\
\hline 1 & 80 & $>1 / 2$ & 1 & - & 27 & None & Colon, mediastinal lymph node \\
2 & 51 & $<1 / 2$ & 1 & + & 60 & None & Paraaortic lymph node \\
3 & 39 & $<1 / 2$ & 3 & - & 67 & CCRT & Lung \\
4 & 56 & $>1 / 2$ & 2 & + & 15 & None & Paraaortic lymph node \\
5 & 56 & $<1 / 2$ & 1 & - & 106 & CCRT & Vagina, distal rectum, bladder, mesorectal tissue \\
6 & 57 & $<1 / 2$ & 3 & + & 12 & None & Liver, paraaortic lymph node \\
7 & 74 & $>1 / 2$ & 3 & + & 113 & None & Pelvis, peritoneal seeding \\
8 & 56 & $>1 / 2$ & 2 & + & 27 & Chemotherapy & Vagina \\
\hline
\end{tabular}

LVSI, lymphovascular involvement; CCRT, concurrent chemoradiation. 


\title{
KOREAN JOURNAL OF OBSTETRICS \& GYNECOLOGY
}

\author{
KJOG Vol. 55, No. 2, 2012
}

oid endometrial cancer, and this was similar to the results of previous studies.

The influence of LVSI on the prognosis of patients with an early stage of endometrial cancer is not clear. LVSI was an independent factor for predicting vaginal relapse in patients with low-risk stage I disease in one study [15]. Mariani et al. [20] suggested that LVSI is strong indicator to predict extra-abdominal failure and survival in patients with positive peritoneal cytologic findings. In another study that included only patients with stage 1 disease of the endometrioid type, LVSI was not useful to predict vaginal relapse [21]. Another study that included stage I endometrial cancer patients reported that only deep myometrial invasion was a predictor of distant metastasis [2]. In the present study, a higher tumor grade, age $>50$ years, and the presence of LVSI was associated with recurrence on univariate analysis $(P<0.05)$. However, the interaction between each histopathologic parameter also was strong and the relative importance of each histopathologic parameter as independent prognostic factors should be evaluated in a future study. Moreover, there was no significant histopathologic parameter on multivariate analysis. Higher grade and deepr myometrial invasion was not associated with prognosis in multivariate analysis in the present study. And myometrial invasion more than $1 / 2$ can be change stages, however, deeper myometrial invasion had no significance multivariate analysis in this study. Therefore, it is uncertain that LVSI has independent prognostic significance or LVSI has an interaction with other prognostic factors.

LVSI is a certain step for tumor progression to metastasis, and it may be an indicator of the possibility of metastasis. Vascular invasion by tumor cells was an important prognostic factor in other studies for several other cancers $[1,2,8]$ and the importance of LVSI as a predictor for lymph node metastasis was proven $[1,9]$. The recurrence rate in our present study was 4.8\% (8 patients). The median time to recurrence was 27 months (range, 12 to 106 months). Five patients who were positive for LVSI developed recurrence at the para-aortic lymph nodes, the liver, and the vagina, and peritoneal seeding also occurred. Three patients who were negative for LVSI showed metastases to various pattern including both locoregional and distant metastases such as colon, mediastinal lymph node, lung metastasis, vagina, distal rectum, bladder, and mesorectal tissue. Three of five patients who were positive for LVSI showed paraaortic lymph node metastasis. However, the sites of recurrence showed more cases of distant metastasis rather than locoregional relapse in both groups. Therefore, each risk factor would interact rather than LVSI being a single prognostic factor. Given the association of LVSI with recurrence, postoperative adju- vant radiotherapy for patients who are positive for LVSI with early stage endometrial cancer is questionable. There is no consensus about adjuvant therapy for treating early stage endometrial cancers with or without LVSI. Some investigators have suggested that treatment should be decided after considering other prognostic factors, because external beam pelvic radiotherapy did not have an impact on vaginal control or survival [22]. A recent meta-analysis shows that external beam pelvic radiotherapy after hysterectomy for low-risk disease increased the odds of death [23]. Therefore, the patients in this study were treated according to each clinician's decision with consideration of other prognostic pathologic variables than just LVSI.

We believe that the present study is valuable because of the relatively uniform data set, because the cases were limited to uterineconfined disease and endometrioid cytology. The limitations of this study are the small number of patients and the inconsistent surgical staging, and the fact that lymph node dissection was not done in some patients. Many patients did not undergo para-aortic lymph node dissection. Because the number of dissected lymph nodes was variable, differences of surgical skill should also be considered. Further, the modality of postoperative adjuvant treatment was not consistent.

In conclusion, LVSI was associated with other prognostic factors such as myometrial invasion, a higher tumor grade, and old age in the patients with uterine-confined endometrioid endometrial cancer. Univariate analysis showed that LVSI was associated with recurrence, but there was no statistical significance found with multivariate analysis. The precise relationship between LVSI and the outcome could have been determined if we had a larger patient population. The treatment modality for patients with uterineconfined endometrioid endometrial cancer should be determined after considering other prognostic factors along with LVSI, because LVSI influences survival by its interaction with other prognostic factors.

\section{References}

1. Morrow CP, Bundy BN, Kurman RJ, Creasman WT, Heller $P$, Homesley HD, et al. Relationship between surgical-pathological risk factors and outcome in clinical stage I and II carcinoma of the endometrium: a Gynecologic Oncology Group study. Gynecol Oncol 1991;40:55-65.

2. Mariani A, Webb MJ, Keeney GL, Lesnick TG, Podratz KC. Surgical stage I endometrial cancer: predictors of distant failure 


\section{KOREAN JOURNAL OF OBSTETRICS \& GYNECOLOGY}

Soyi Lim, et al. LVSI in early stage endometrial cancer

and death. Gynecol Oncol 2002;87:274-80.

3. Zaino RJ, Kurman RJ, Diana KL, Morrow CP. Pathologic models to predict outcome for women with endometrial adenocarcinoma: the importance of the distinction between surgical stage and clinical stage: a Gynecologic Oncology Group study. Cancer 1996;77:1115-21.

4. Roman LD, Felix JC, Muderspach LI, Varkey T, Burnett AF, Qian $D$, et al. Influence of quantity of lymph-vascular space invasion on the risk of nodal metastases in women with early-stage squamous cancer of the cervix. Gynecol Oncol 1998;68:220-5.

5. O'Hanlan KA, Kargas S, Schreiber M, Burrs D, Mallipeddi P, Longacre $T$, et al. Ovarian carcinoma metastases to gastrointestinal tract appear to spread like colon carcinoma: implications for surgical resection. Gynecol Oncol 1995;59:200-6.

6. Paladini D, Cross P, Lopes A, Monaghan JM. Prognostic significance of lymph node variables in squamous cell carcinoma of the vulva. Cancer 1994;74:2491-6.

7. Katz A, Strom EA, Buchholz TA, Theriault R, Singletary SE, McNeese MD. The influence of pathologic tumor characteristics on locoregional recurrence rates following mastectomy. Int J Radiat Oncol Biol Phys 2001;50:735-42.

8. Hanson MB, van Nagell JR Jr, Powell DE, Donaldson ES, Gallion $\mathrm{H}$, Merhige $\mathrm{M}$, et al. The prognostic significance of lymphvascular space invasion in stage I endometrial cancer. Cancer 1985;55:1753-7.

9. Creasman WT, Morrow CP, Bundy BN, Homesley HD, Graham $J E$, Heller PB. Surgical pathologic spread patterns of endometrial cancer. A Gynecologic Oncology Group Study. Cancer 1987;60:2035-41.

10. Boronow RC, Morrow CP, Creasman WT, Disaia PJ, Silverberg $S G$, Miller $A$, et al. Surgical staging in endometrial cancer: clinical-pathologic findings of a prospective study. Obstet Gynecol 1984;63:825-32.

11. Cohn DE, Horowitz NS, Mutch DG, Kim SM, Manolitsas T, Fowler JM. Should the presence of lymphvascular space involvement be used to assign patients to adjuvant therapy following hysterectomy for unstaged endometrial cancer? Gynecol Oncol 2002;87:243-6.

12. Mariani A, Dowdy SC, Keeney GL, Haddock MG, Lesnick TG, Podratz KC. Predictors of vaginal relapse in stage I endometrial cancer. Gynecol Oncol 2005;97:820-7.
13. Mariani A, Webb MJ, Keeney GL, Aletti G, Podratz KC. Predictors of lymphatic failure in endometrial cancer. Gynecol Oncol 2002;84:437-42.

14. Briet JM, Hollema H, Reesink N, Aalders JG, Mourits MJ, ten Hoor KA, et al. Lymphvascular space involvement: an independent prognostic factor in endometrial cancer. Gynecol Oncol 2005;96:799-804.

15. Ambros RA, Kurman RJ. Combined assessment of vascular and myometrial invasion as a model to predict prognosis in stage I endometrioid adenocarcinoma of the uterine corpus. Cancer 1992:69:1424-31.

16. Tsuruchi N, Kaku T, Kamura T, Tsukamoto N, Tsuneyoshi M,

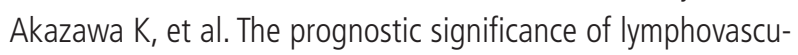
lar space invasion in endometrial cancer when conventional hemotoxylin and eosin staining is compared to immunohistochemical staining. Gynecol Oncol 1995;57:307-12.

17. Kadar N, Malfetano JH, Homesley HD. Determinants of survival of surgically staged patients with endometrial carcinoma histologically confined to the uterus: implications for therapy. Obstet Gynecol 1992;80:655-9.

18. Inoue Y, Obata K, Abe K, Ohmura G, Doh K, Yoshioka T, et al. The prognostic significance of vascular invasion by endometrial carcinoma. Cancer 1996;78:1447-51.

19. Nishiya M, Sakuragi N, Hareyama H, Ebina Y, Furuya M, Oikawa $\mathrm{M}$, et al. Cox multivariate regression models for estimating prognosis of patients with endometrioid adenocarcinoma of the uterine corpus who underwent thorough surgical staging. Int J Cancer 1998;79:521-5.

20. Mariani A, Webb MJ, Keeney GL, Aletti G, Podratz KC. Assessment of prognostic factors in stage IIIA endometrial cancer. Gynecol Oncol 2002;86:38-44.

21. Desrosiers L, Fadare O, Xiao ZF, Dresser K, Wang SA. Lymphovascular space invasion does not predict vaginal relapses in stage I endometrioid adenocarcinoma of the endometrium. Ann Diagn Pathol 2008;12:112-7.

22. Croog VJ, Abu-Rustum NR, Barakat RR, Alektiar KM. Adjuvant radiation for early stage endometrial cancer with lymphovascular invasion. Gynecol Oncol 2008;111:49-54.

23. Johnson N, Cornes P. Survival and recurrent disease after postoperative radiotherapy for early endometrial cancer: systematic review and meta-analysis. BJOG 2007;114:1313-20. 


\section{자궁에 국한된 자궁내막암에서 림프혈관 침윤의 예후인자로서의 중요성}

가천의과학대학교 길병원 산부인과

임소이, 이광범, 박찬용

목적

자궁에 국한된 자궁내막모양형의 자궁내막암 환자에서 림프혈관 침윤이 재발의 위험인자인지를 조사하였다.

연구방법

1998년부터 2010년까지 전자궁절제술, 양측 난소난관절제술, 복강세척 세포검사 및 림프절절제술 또는 자궁절제술, 양측 난소난관절제 술, 복강세척 세포검사를 시행받은 자궁에 국한된 자궁내막모양형의 자궁내막암 환자 165 명의 의무기록을 후향적으로 조사하였다. 복강 세척 세포검사가 양성으로 나온 환자를 제외하지는 않았다.

결과

나이의 중간값은 52세였다(범위, 26-81세). 평균 추적기간은 46개월이었다(범위, 1-144개월). 124명(75.2\%)은 보조적 치료를 받지 않 았고, 41명(24.8\%)은 항암화학요법, 방사선 치료, 동시 항암방사선요법의 치료를 받았다. 림프혈관 침윤은 29명(17.6\%)의 환자에서 있었 다. 8명(4.8\%)에서 재발이 발생하였다. 단인자 분석상 50세 이상의 연령, 종양의 분화도, 림프혈관 침윤이 재발없는 생존과 연관이 있었다 $(P<0.05)$. 림프혈관 침윤은 종양의 분화도, 고령, 자궁근층 침윤과 같은 다른 예후 인자들과도 상호연관이 있었다. 그러나 다인자 분석에 서는 통계적 의의를 보이지 않았다. 림프혈관 침윤은 재발을 예측하는 독립적 인자가 아니었다 $(P=0.093)$.

결론

림프혈관 침윤은 자궁에 국한된 자궁내막모양형의 자궁내막암 환자에서 단인자 분석상 재발과 연관이 있는것으로 나타났으나 다인자 분 석에서는 통계적 의미가 없었다. 림프혈관 침윤 그 자체로는 예후에 영향이 없는 것으로 보이며, 단독으로 치료계획을 정하거나 예후를 예 측하지는 못할 것으로 생각된다.

중심단어: 자궁내막암, 림프혈관 침윤, 재발 